\title{
Staking a Claim: Dispute, Displacement and Galician Identity in Marta Rivera de la Cruz's Hotel Almirante (2002)
}

\author{
CATHERINE BARBOUR \\ University of Surrey
}

\begin{abstract}
Ignoro completamente qué sucedería si yo, en vez de ensalzar, describir y retratar, agotando todo mi sentimiento, que tarda más en agotarse que mi ingenio al país donde nací, me hubiese encerrado respecto a él en completo silencio, o hubiese dicho a las gentes que me leen que esta tierra ni merece verse, ni visitarse, ni ser amada. (Emilia Pardo Bazán) ${ }^{1}$
\end{abstract}

Arguably, few writers have caused as much controversy in the Galician press in recent years as the prolific novelist and diputada for Ciudadanos, Marta Rivera de la Cruz (b. 1970), who occupies a somewhat ambivalent space between the Galician and Spanish cultural systems. Born and raised in the Galician city of Lugo, Rivera insists on her status as a Galician writer, even though she publishes exclusively in Spanish and is a fervent critic of the institutionalization of the Galician language. ${ }^{2}$ She has held various prominent roles in the Spanish government and is renowned for her outspoken views which are very much at odds with the Galician nationalist project. ${ }^{3}$ As Helena Miguélez-Carballeira reminds us, 'open considerations of the distinctiveness—or even simple existence — of Galician culture are rare

1 From a document archived at the Casa-Museo Emilia Pardo Bazán, A Coruña; cited in Carmen Pereira-Muro, Género, nación y literatura: Emilia Pardo Bazán en la literatura gallega y española (West Lafayette/London: Purdue U. P., 2012), 74.

2 Marta Rivera de la Cruz, 'Entrevistas Digitales: los lectores preguntan a Marta Rivera de la Cruz', El Pais, 10 November 2006, n.p.; available at $<$ https://elpais.com/cultura/2006/11/10/actualidad/1163160000_1163162420.html> (accessed 12 April 2019).

3 For a current list of Rivera's government roles and responsibilities, see the Congreso de Diputados webpage; available at <http://www.congreso.es/portal/page/portal/Congreso/Congreso/Diputados/BusqForm?_piref7 3_1333155_73_1333154_1333154.next_page=/wc/fichaDiputado?idDiputado=98\&idLegislatu ra=12> (accessed 12 April 2019). 
in Spanish mainstream media discourses', and there remains an endemic lack of acknowledgement of Galicia's cultural difference beyond regional cliché in Spanish textual production. ${ }^{4}$ If Rivera's bestsellers serve as an entry point into Galicia for Spanish readers, they reinforce certain stereotypical tropes of 'regional identity' that comply with state centralism, through the mythologization of Galicia's remote location, feudal society and exquisite cuisine. Yet her novels also toy with progressive notions of Galician culture, contesting tradition in such a way that complicates reading them as merely a manifestation of the Spanish regionalist ideology that the author promotes in the public sphere. It is argued here that by tackling the highly politicized and often contentious - though admittedly, widespread-interpretation of Galicia found in Rivera's work, in this case through close analysis of her popular novel Hotel Almirante (2002), we become party to her conflicted relationship with the Galician cultural sphere, which in turn demonstrates the diverse, and at times unsettling, facets of Galician cultural identity that conflict and converge with the Galician national project. This is most apparent in the textual interplay of territory, class and gender, elements which no doubt influence the treatment of Rivera by the Galician cultural sphere as a female member of the Spanish political elite living outwith the community, and represent some of the most salient markers of 'reflective' identity, to borrow Patrick Colm Hogan's term for the 'hierarchized set of properties and relations which one takes to define oneself'. ${ }^{5}$ We consider the extent to which these particular dimensions in the text are informed by Rivera's ideology, through examination of how this relates to her position as a Galician woman writer and politician for the centre-right who resides in Madrid and writes in Spanish, "proviene del franquismo, con abuelo concejal franquista y padre periodista del régimen' and has married into the Galician aristocracy (her husband is the Marqués de Almeiras). ${ }^{6}$

A brief examination of the tensions in Galician-Spanish relations, and how these are reflected in Galician language politics and the cultural sphere, is key to understanding Rivera's conflicted profile in the Galician public arena. The distinct language, culture, history and identity of Galicia has historically been allocated a very precise location within the centralizing Spanish state, subjected to centuries of economic exploitation and political oppression which culminated in the Civil War and dictatorship of Francisco Franco in the twentieth century and said to be the region of Spain 'most

4 Helena Miguélez-Carballeira, 'An Introduction to Galician Culture', in A Companion to Galician Culture, ed. Helena Miguélez-Carballeira (Woodbridge: Tamesis, 2014), 1-12 (p. $3)$.

5 Patrick Colm Hogan, Colonialism and Cultural Identity: Crises of Tradition in the Anglophone Literatures of India, Africa, and the Caribbean (New York: State Univ. of New York Press, 2000), 322.

6 Antonio Maestre, 'El clasismo de la candidata de Ciudadanos, Marta Rivera de la Cruz', La Marea, 14 October 2015, n.p.; available at <https://www.lamarea.com/2015/10/14/elclasismo-de-la-candidata-de-ciudadanos-marta-rivera-de-la-cruz/> (accessed 12 April 2019). 
profoundly mediated by the dynamics of political, economic and cultural inequities throughout the centuries'. ${ }^{7}$ The centre-periphery binary has engendered conflict between identities, ideologies, languages and literatures, as the state has attempted to contain Galician cultural difference within a discourse of regionalism that it can control: 'lingua, nación e literatura son, no fondo, categorías políticas, cargadas e construídas pola "forza" da nación que o "poder" do estado quere degradar a dialecto, rexión e tradición local'. 8 These tensions are apparent throughout textual production from Galicia.

Reflecting the unequal power relation between the nation-state and the non-state, Galician society has historically been defined by linguistic diglossia, the coexistence of a dominant and a minority language in a determined geo-cultural space, in that Spanish has been imposed as the language of social prestige, to the detriment of the autochthonous tongue. ${ }^{9}$ Beginning in the Renaissance period, the Spanish Empire gradually enforced Castilian Spanish as the lingua franca throughout its territories, attempting to obliterate other languages and dialects. As Michael Billig purports in his study of 'banal nationalism', 'the creation of a national hegemony often involves a hegemony of language', with both language and nation existing as 'invented permanencies' reproduced in daily life, which may be accepted as neutral features of society, but which in fact consist of ideological constructs that gained prominence according to determined socio-political factors, for 'language does not create nationalism, so much as nationalism creates language; or rather nationalism creates "our" common-sense, unquestioned view that there are, "naturally" and unproblematically, things called different "languages" which we speak'.10 Both Galician and Spanish nationalisms tend towards Benedict Anderson's elevation of language as the utopian touchstone of national identity, as with the rise of nation-states and national identities in the nineteenth century that provoked the Rexurdimento cultural revival, the Galician language became an important marker for delineating cultural difference. ${ }^{11}$ Despite severe linguistic repression until the end of the dictatorship in 1975, and in the face of enduring social prejudice, with co-official status and standardization only fully realized as late as 1983, the Galician language has proved resilient. Since the transition to democracy, commendable progress has been made in securing its implementation in literary, cultural, social and political life in Galicia, though the future remains uncertain, particularly as globalization

7 Miguélez-Carballeira, 'An Introduction to Galician Culture', 2.

8 Manuel Forcadela, Dama Saudade e o cabaleiro Sombra: as relacións entre o imaxinario literario e o imaxinario nacional na literatura galega contemporánea (Berlin: Frank \& Timme, 2013), 16.

9 See Joshua A. Fishman, 'Bilingualism with and without Diglossia; Diglossia with and without Bilingualism', Journal of Social Issues, 23:2 (1967), 29-38.

10 Michael Billig, Banal Nationalism (London: Sage Publications, 1995), 29-30.

11 Benedict Anderson, Imagined Communities: Reflections on the Origin and Spread of Nationalism (London: Verso, 2006), 154. 
tightens its grip.

Though the purpose of this article is not to debate the tenets of Galician literature so much as to examine the more conservative side of Galician culture and its impact on identity construction, a consideration of linguistic boundaries is necessary for due acknowledgement of the implications of a text written by a Galician author in Spanish. Galician literature, which historically stands as the repository of Galician national identity, and the related study of Galician philology, is generally defined by what Xoán González-Millán referred to as the 'criterio filolóxico', as it for the most part exclusively includes texts published in the Galician language, just as the counterparts of Spanish literature and Spanish literary studies relate to texts written in Spanish, thereby excluding the many writers within the boundaries of the Spanish state who write in one of its other co-official languages. ${ }^{12}$ Ricardo Carballo Calero's Historia da literatura galega contemporánea, first published in 1962, has been highly influential in reifying this definition, as it continues to be venerated by Galician philologists as a vital source of reference, despite the extent to which it delimits cultural history to Galician-language, nationalist writing by men. ${ }^{13}$ Yet it has been shown that many Galician citizens were in fact initially hesitant about the rigid application of a monolingual understanding of the national literature which did not reflect Galicia's bilingual (diglossic) society. ${ }^{14}$ Such linguistic parameters bar those who write in Spanish from what has been coined as 'literary citizenship' by Mario Santana to denote exclusive inclusion in a literary community, and since appropriated by Kirsty Hooper and María Liñeira for the Galician context. ${ }^{15}$ Rivera provocatively challenges the monolingual conditioning of Galician literature by claiming to be 'máis escritora galega que moitos que escriben en galego'. ${ }^{16}$ Of course, the linguistic criterion is to a certain extent more universalizing than a 'criterio étnico' that allows for texts by any Galician-born writer, in that it includes the Galician-language work of the children of Galician emigrants born abroad, as well as exophonic writers-non-Galician Spaniards and foreign nationals who have chosen to write in Galician. However, it implies that their work is 'more Galician' than that of those born in Galicia who write in

12 See Xoán González-Millán, 'O criterio filolóxico e a configuración dunha literatura nacional: achegas a un novo marco de reflexión', Cuadernos de lingua, 17 (1998), 5-24.

13 See Helena Miguélez-Carballeira, Galicia, a Sentimental Nation (Cardiff: Univ. of Wales Press, 2013), 135-75.

14 See María Liñeira, 'Literary Citizenship and the Politics of Language: The Galician Literary Field between 1939 and 1965', PhD thesis (University of Oxford, 2015).

15 See Mario Santana, Foreigners in the Homeland: The Spanish American New Novel in Spain, 1962 - 1974 (Lewisburg, PA: Bucknell University Press, 2000), 17-32 and Kirsty Hooper, Writing Galicia into the World: New Cartographies, New Poetics (Liverpool: Liverpool U. P., 2011), 22.

16 Rivera, cited in Kirsty Hooper, 'Girl, Interrupted: The Distinctive History of Galician Women's Narrative', Romance Studies, 21:2 (2003), 101-14 (p. 111). 
Spanish. Manuel Forcadela examines the influence of the 'criterio temático', which considers how the thematic content of a text relates to the national imaginary, yet this remains illusory, contradictory and open to interpretation, and even as this is challenging to demarcate, a more fluid combination of these competing factors could account for the diverse texts which contribute to Galician culture. ${ }^{17}$ The nationalization of Galician literature has been heavily scrutinized in recent scholarship, and there has been increasing acknowledgement of the role of Spanish-language texts in fostering Galician identity. Still ingrained, however, are the erroneous assumptions that Spanish-language Galician writers inevitably have rightwing sympathies, or indeed that those who write in Galician always prioritise Galician nationalism. Texts by Galician-born writers which engage in some way with the Galician imaginary, regardless of the language they were written in or the political ideology which influences them, can give insight into the complex, conflicting discourses that inform Galician culture.

Literary systems are inherently conditioned by the political, and because of its 'minoritized' condition the Galician case in particular holds 'unha importancia socio-política que vai moito máis alá do puramente estético o cultural'. ${ }^{18}$ Xoán González-Millán influentially pitted the historical role of nacionalismo literario, the intense political dependency on the literary sphere for self-determination, against a literatura nacional which would be based on aesthetic quality. ${ }^{19}$ Indeed, for non-state national literatures, the focus on upholding the national project places unnatural pressure on the literary system, so that the reception of a text in a diglossic context is always a politicized process. ${ }^{20}$ Commercial and editorial pressures, political leanings and, interestingly, linguistic competence, are among the factors which contribute to a writer's decision to choose one language over the other, and Rivera cites reduced linguistic ability as a factor that dissuades her from publishing in Galician. ${ }^{21}$ As Hooper notes, the pressure for writers to negotiate the issue of 'language choice' does not reflect the linguistic and cultural plurality of contemporary Galician society, as it

17 See Forcadela, Dama Saudade e o cabaleiro Sombra, 21.

18 Inmaculada López Silva, 'Escritores, lingua e identidade: o exemplo da literatura galega contemporánea', Ianua. Revista Philologica Romanica, 2 (2001), 106-24 (p. 106).

19 See Xoán González Millán, 'Do nacionalismo literario a unha literatura nacional: hipóteses de traballo para un estudio institucional da literatura galega', Anuario de Estudos Literarios Galegos (1994), 67-81, and his 'Nacionalismo literario y teoría del campo literario: la experiencia gallega de las últimas décadas', in From Stateless Nations to Postnational Spain/De naciones sin estado a la España postnacional, ed. Silvia Bermúdez, Antonio Cortijo Ocaña \& Timothy Michael McGovern (Boulder: Society of Spanish and Spanish-American Studies, 2002), 223-36.

20 See Antón Figueroa, Diglosia e texto (Vigo: Xerais de Galicia, 1988).

21 'Marta Rivera acusa as institucións galegas de marxinala por no escribir no idioma do país', Galicia Hoxe, 17 October 2006, n.p.; available at $<$ http://www.galiciahoxe.com/mare/gh/marta-rivera-acusa-as-institucions-galegasmarxinalaescribir-no-idioma-do-pais/idEdicion-2006-10-17/idNoticia-94220/> (accessed 12 April 2019). 
[...] create[es] an ever increasing gulf between the institutionalized culture for which language has become a key element in identitydefinition, and the lived reality of most Galicians, which involves a constant balancing act between Galician and Spanish cultures, languages, and identities. ${ }^{22}$

Writers who engage with the Galician cultural scene in any way are constantly taken to task over their 'language choice' and political affiliation, however this negates the complex interplay of discourses in Galician identity.

Rivera's self-professed 'displacement' from Galician culture as a Spanishlanguage writer is bolstered by her inflammatory public profile, right-wing politics and open rejection of both the Galician language and Galician nationalism. Particularly striking is the extent to which her palpable but contested role in Galician culture recalls that of several notable Galician writers who have published in Spanish, such as the aristocratic Emilia Pardo Bazán, who maintained a notoriously tenuous relationship with Galician regionalists at the end of the nineteenth century. Yet in his study of Pardo Bazán's work, Joseba Gabilondo suggests that 'even when the work of a writer is fully assimilated into a specific canon-the state canon of Spanish literature written in Spanish-the traces of the other language and geography (Galicia/n) remain'. ${ }^{23}$ Whilst the linguistic influences on Rivera's literary production remain outside the scope of this article (though it should be noted that her texts make almost no use of the Galician language whatsoever, unlike other writers whose work contains even occasional phrases in Galician), we consider the extent to which Hotel Almirante draws on her cultural heritage in a way which challenges assumptions about Galician identity. Owing to her controversial approach, Rivera's work has yet to be examined in the context of Galician Studies, even though Hooper reminds us that 'we certainly cannot ignore her voice, which throws into sharp relief the existence of alternative-and often conflicting and controversial-interpretations of Galicianness'. ${ }^{24}$ In Hooper's proposal of what she terms 'lecturas relacionais', drawing from Édouard Glissant's 'poetics of relation' as a means to theorize the reading of texts beyond established parameters, she emphasizes the urgency to 'practicar lecturas, buscar xeitos de ler, que, sen suxeitárense aos modelos dominantes, saiban recoñecer tanto o seu poder imperecedoiro como as súas implicacións

22 Kirsty Hooper, “"This Festering Wound": Negotiating Spanishness in Galician Cultural Discourse', in Spanishness in the Spanish Novel and Cinema of the 20th-21st Century, ed. Cristina Sánchez-Conejero (Newcastle-upon-Tyne: Cambridge Scholars' Press, 2007), 14756 (p. 149).

23 Joseba Gabilondo, 'Towards a Postnational History of Galician Literature: On Pardo Bazán's Transnational and Translational Position', BHS, LXXXVI:2 (2009), 249-69 (p. 252).

24 Hooper, 'Girl, Interrupted', 111. 
pragmáticas'. ${ }^{25}$ The present study takes Hooper's reflections as a starting point, heeding the call of Olga Castro and María Liñeira for 'a new understanding of Galician Literary Studies that instead of shying away from conflict seeks to engage with it', by suggesting that the need to interrogate Rivera's fiction within and beyond the field has become ever more pressing, as the writer becomes increasingly prominent on the political as well as cultural stage. ${ }^{26}$

Like millions of Galicians past and present, Rivera is herself an emigrant (albeit internally within the Spanish state), having resided in Madrid since commencing her university studies. For many years, she worked for the Spanish-language press and television and garnered a reputation as a highly influential journalist, experience which no doubt facilitated her move into politics. Several members of Rivera's family work in the media, and her father Francisco Rivera Cela, who is particularly recognized for his work with the moderate newspaper El Progreso, as well as on radio (especially for the conservative Catholic station COPE), began working as a journalist during Franco's dictatorship. In her youth, Rivera also collaborated with COPE, as well as with the right-wing Partido Popular (PP). ${ }^{27}$ In 2015, she became a Member of the Spanish Assembly with the centre-right party Ciudadanos, which has encroached upon Spain's traditionally bipartite political arena since it was launched in Catalonia in $2006 .{ }^{28}$ In keeping with one of the party's key aims to contest nationalist movements in Spain's historic nationalities, Rivera asserts a conservative stance on Galician language politics, as she comments 'la política cultural en Galicia se ha reducido a una política lingüística en favor del gallego. Y la cultura la integran muchas más cosas que el idioma'. ${ }^{29}$ Indeed, she has gone so far as to write a manifesto in support of 'Galicia Bilingüe', a platform supposedly

25 Kirsty Hooper, 'Unha nova volta ás cartografías da cultura galega: lecturas postnacionais, lecturas relacionais', Galica 21, D (2012), 44-56 (p. 54).

26 Olga Castro \& María Liñeira, 'Exploring Nooks and Crannies', Abriu, 4 (2015), 9-11 (p. 11).

27 Rivera mentions her work for the PP in Gádor Cascales, 'Albert Rivera me pidió los próximos cuatro años de mi vida para mi país y me convenció', El Progreso, 27 July 2015, n.p.; available at <http://elprogreso.galiciae.com/noticia/420596/albert-rivera-me-pidio-losproximos-cuatro-anos-de-mi-vida-para-mi-pais-y-me> (accessed 12 April 2019).

28 For discussion of the ideological trajectory of Ciudadanos, see for example Carmen Moraga, 'Ciudadanos: doce años de virajes ideológicos para acabar compitiendo por la derecha con el PP', El Diario, 26 August $2018<$ https:/www.eldiario.es/politica/CiudadanosAlbert_Rivera-vaivenes-ideologia-alianzas_0_806670041.html> and Kate Shea Baird, 'The naked truth about Ciudadanos, Spain's counter-revolutionaries', Open Democracy, 5 April 2015 <https://www.opendemocracy.net/can-europe-make-it/kate-shea-baird/naked-truthabout-ciudadanos-spain's-counterrevolutionaries> (both accessed 12 April 2019).

29 M.A.G., 'Marta Rivera de la Cruz: "Enseñar en gallego porque el castellano se aprende con la tele es una irresponsibilidad" ', La Voz Libre, 8 July 2009, n.p.; available at $<$ https://hemeroteca.vozlibre.com/noticias/ampliar/4734/marta-rivera-de-la-cruz-ensenar-engallego-porque-el-castellano-se-aprende-con-la-tele-es-una-irresponsabilidad> (accessed 12 April 2019). 
promoting bilingualism in Galician society which in the words of Bernadette O'Rourke, projects 'a strongly anti-Galician discourse' and recalls former President of the Galician Xunta Manuel Fraga's fundamentally Spanish nationalist legacy of 'bilingüísmo harmónico', a marketing ploy which served to pay lip service to the 1983 Lei de Normalización Lingüística without implementing it. ${ }^{30}$ The project is generally considered by the Left to be a barely disguised drive to further impose Spanish in all aspects of daily life, promoting an essentially Spanish nationalist agenda that is in keeping with Ciudadanos policies, for as Juan Carlos Moreno Cabrera explains, though the state claims neutrality, it employs similar ideological strategies to nonstate nationalist groups:

[...] las actuaciones de los denominados grupos no nacionalistas también se fundamentan en la defensa y promoción de una lengua, una cultura étnica y un poder político de una nación concreta y por tanto son igualmente nacionalistas. ${ }^{31}$

In her manifesto, Rivera claims that the imposition of Galician renders Spanish-speakers 'extranjeros en nuestra propia patria', a turn of phrase that presents an uncomfortable and no doubt deliberate allusion to the title of the well-known poem by Galicia's poet laureate Rosalía de Castro. ${ }^{32}$ If

30 Marta Rivera de la Cruz, 'Carta de apoyo de Marta Rivera de la Cruz', Galicia Bilingüe, n.p.; available at <http://galiciabilingue.es/gb/2008/04/20/carta-de-apoyo-de-martarivera-de-la-cruz/> (accessed 12 April 2019). See Bernadette O'Rourke, 'The Galician Language in the Twenty-First Century', in A Companion to Galician Culture, ed. MiguélezCarballeira, 73-92 (p. 85).

31 Juan Carlos Moreno Cabrera, 'El nacionalismo lingüístico español', in Nacionalismo español: esencias, memorias e instituciones, dir. Carlos Taibo (Madrid: Los Libros de la Catarata, 2007), 351-76 (p. 356).

32 See Rosalía de Castro, 'Estranxeira na súa Patria' in Follas Novas, ed. Teresa Bermúdez (Vigo: Galaxia, 2016), poem 32. Incidentally, Rivera was invited to pay homage to Rosalía de Castro by the right-wing autonomous government on International Women's Day in 2013, as this coincided with the noteworthy one hundred and fiftieth anniversary of the publication of Rosalía de Castro's Cantares gallegos in 1863, which is said to have sparked the beginning of the Rexurdimento cultural renaissance. The fact that a Spanish-language writer, known for her criticism of Galician language policy, was chosen to mark the Galician cultural revival caused an uproar in the Galician press. In further controversy, Rivera referred to the city officially named A Coruña as 'La' Coruña', using the Spanish definite article. In response, she threatened to Castilianize other Galician place names (such as Rianxo to Rianjo), a move close to recalling the erasure of Galician toponyms under Francoism. See Beti Vázquez, 'Marcha Mundial: "O acto da Xunta, máis que celebrar o 8 de marzo, será un insulto á memoria de Rosalía”,', Sermos Galiza, 8 March 2013, n.p.; available at $<$ http://www.sermosgaliza.gal/articulo/social/

marcha-mundial-con-rivera-de-la-cruz-mais-que-un-acto-do-8-de-marzo-sera-un-insulto-amemoria-de-rosalia-un-8-de-marzo/20130307230422012152.html> (accessed 12 April 2019), and M.L., 'A escritora Marta Rivera de la Cruz perde os nervios na defensa de "La Coruña", Sermos Galiza, 6 February 2014, n.p.; available at $<$ http://www.sermosgaliza.gal/articulo/cultura/escritora-marta-rivera-perde-nervios-na- 
language is itself a coded social construction which exerts control and mediates the spread of ideology, the site of what Pierre Bourdieu terms 'misrecognition' of power relations in that it reifies certain cultural practices, Rivera's literary practice abides by her political stance. ${ }^{33}$ Although she has given interviews and published a handful of journalistic articles in Galician, none of her novels have been translated into the language, yet La boda de Kate (2014) has been translated into Italian and German.

Despite having achieved substantial commercial success in Galicia, Rivera reports feeling excluded from local institutions (and thus being denied so-called 'literary citizenship') for not writing in Galician. ${ }^{34}$ Interestingly, however, Hotel Almirante was adapted into a mini-series which premiered on local television in April 2015, rendering the novel particularly significant in terms of evaluating Rivera's contribution to local culture. The production, which was shot in Lugo and A Coruña with an all-Galician cast of well-known actors such as Ana Turpin and Xoque Carbajal, and subsequently released as a full-length feature film, generated considerable media hype. The fact that a Spanish-language writer considered polemical by many in the Galician cultural sphere succeeded in making a symbolic contribution to Galician television was naturally met with disdain in the nationalist press, especially given that there continue to be many successful Galician-language novels that have not been adapted for televised series. ${ }^{35}$ Even so, this adaptation of a Spanish-language text with a non-nationalist view of Galicia suggests that not all practitioners in the Galician cultural sphere take issue with Rivera's stance, particularly in the auspices of a right-wing regional government. This undermines the writer's insinuation that she is marginalized by institutions and highlights her multifaceted and often contradictory relationship with Galician language and culture.

We turn now to a discussion of how these various issues play out in Rivera's fiction, interrogating how it is consciously or otherwise infiltrated by the author's ideology and circumstance, for as Forcadela reiterates, 'todo relato supón unha idealoxía, unha posición concreta perante o sistema político no que se leva a cabo a súa produción, podendo ser esta postura tanto

defensa-coruna-onde-presenta-seu-novo-libro/201402061641370238

84.html> (accessed 12 April 2019).

33 Pierre Bourdieu, The Field of Cultural Production: Essays on Art and Literature, ed., with an intro., by Randal Johnson (Cambridge: Polity Press, 1993), 81.

34 Anon., 'Marta Rivera acusa as institucións galegas de marxinala por no escribir no idioma do país', Galicia Hoxe, 17 October 2006, n.p.; available at $<$ http://www.galiciahoxe.com/mare/gh/marta-rivera-acusa-as-institucions-galegasmarxinala-escribir-no-idioma-do-pais/idEdicion-2006-10-17/idNoticia-94220/> (accessed 12 April 2019).

35 Anon., 'A TVG lanza unha serie baseada nunha obra dunha escritora crítica coa normalización', Galicia Confidencial, 31 October 2014, n.p.; available at <http://www.galiciaconfidencial.com/nova/21409.html> (accessed 12 April 2019). 
consciente como inconsciente'. ${ }^{36}$ Many characters overlap in Rivera's novels, and Hotel Almirante serves as a prequel to Que veinte años no es nada (1998), and a sequel to Linus Daff, inventor de historias (2000), earlier texts which are also set in Ribanova. A pseudo-detective novel and family drama which draws on the novela negra style, Hotel Almirante takes place in the years immediately following the Spanish Civil War, the conflict which crucially marked a climax in the crisis of Spanish national identity, with flashbacks to the turn of the century. The setting is the provincial city of Ribanova, which significantly in terms of the writer's disputed contribution to Galician culture, is based on her hometown of Lugo. The novel centres on the police investigation into the suicide in the eponymous hotel of a guest named Cristina Sanjuán, a young woman who has no apparent connection to the area. Hotel Almirante has become a symbolic feature of Ribanova since its foundation, with a history based on the longstanding rivalry between two local families, the Leals and the Aldaos. Before the war, a working-class widow named Tana Leal established the hotel of which her granddaughter Rosalía is now the manager in a former property of the wealthy, aristocratic Aldao family, much to their disapproval. Scandal erupts when Cristina's suicide note blames her death on the Aldao's prodigal son Javier, who is living in exile in Madrid having been shunned by his family for siding with the Republicans during the Civil War.

The negotiation between what Rogers Brubaker and Frederic Cooper term 'hard', or static elements of reflective identity, such as one's place of birth, and 'soft', or malleable identity, such as the impact of emigration, is a key concern in literature by displaced writers, even when the displacement is voluntary as in the case of Rivera. ${ }^{37}$ Cultural production from Galicia is particularly marked by this tension between place and displacement, the first theme for discussion here, through the legacy of emigration. Drawing on the Galician case, González-Millán has shown how attitudes to language, culture and ideology become increasingly heterogeneous and conflicting through the interrelated processes of exile and emigration, which complicates linear conceptions of culture. ${ }^{38}$ Indeed, fluid understandings of space and place dominate Rivera's narrative, in a reflection of her assertion of her right to claim a Galician identity. From the outset, the wet, Atlantic climate locates the setting in Galicia, linking the location to the ominous events which are about to unfold. On the first page, the 'viento del Norte' causes a maid to enter Cristina's room to close her window, and so notice that

36 Forcadela, Dama Saudade e o cabaleiro Sombra, 27.

37 See Rogers Brubaker \& Frederic Cooper, 'Beyond "Identity" ', Theory and Society, 29:1 (2000), 1-47.

38 Xoán González-Millán, 'El exilio gallego y el discurso de la restauración nacional', Arizona Journal of Hispanic Cultural Studies, 6 (2002), 7-23 
she is not breathing. ${ }^{39}$ The overcast weather contextualizes the death in the front-page news of the local newspaper:

Ribanova había amanecido pacífica y gris, como todos los días de diciembre, pero la noticia inverosímil de un suicidio en una habitación del Hotel Almirante había venido a quebrar la rutina diaria de la ciudad cercada eternamente por la muralla milenaria. (91)

As the police investigation gets underway however, it begins to snow, an exacerbation of typical Galician rain which symbolizes the social disorder caused by the death of an outsider in a sleepy Galician town. Although the text details events in Madrid, as well as briefly mentioning travels abroad, the small city of Ribanova itself is the focus of the novel. It sports an Alameda park, like Lugo's Parque Rosalía de Castro, and El Casino, a cultural club, which is based on the Círculo de las Artes and named after a similar establishment in Santiago. Rosalía Leal's aunt Rosa marries Cándido Aldao in the Virgen de los Ojos Grandes chapel located within Lugo cathedral. The city is in many ways packaged as an idealized Lugo; a provincial, folkloric space with a tight-knit community. Symbolically located on the periphery, it is isolated by its Lugo-inspired Roman wall, with the stereotype of Galician marginality foregrounded at various points, in a reflection of life under Franco: 'eran muchos los españoles incapaces de situar en el mapa la ciudad bimilenaria' (94). This is further reinforced when Rosa, the only one of the Leals who has been fortunate enough to travel abroad, refers to Ribanova as a city in limbo, 'el último lugar de la tierra' (199). The newspaper $E l$ Comercio, an allusion to the Lugo daily El Progreso in which Rivera's father had a column, is said to be the only link many Ribanova citizens have with the outside world.

Just as Rivera maintains her right to claim a Galician identity, the pull of origins fundamentally dominates the narrative, to the extent that Ribanova is 'una obsesión' (135) for the displaced Javier, just as it is for Cristina, who in reality expresses what Carlos Taibo has described as 'una orgullosa desatención hacía lo periférico' that is typical of state nationalism by developing a romanticized attachment to an essentialist version of Galicia, informed by colonizing mythology and her own lack of fixed roots. ${ }^{40}$ Through movement across borders, singular, linear notions of identity are complicated, as Linda McDowell argues that the idea 'that progress was a single road towards modernization, westernization and urbanization-is challenged by a focus on multiplicity, on travel and intersecting

39 Marta Rivera de la Cruz, Hotel Almirante (Madrid: Espasa, 2002), 9. Further references to the novel are given parenthetically in the text.

40 Carlos Taibo, Sobre el nacionalismo español (Madrid: Los Libros de la Catarata, 2014), 43. 
movements'. ${ }^{41}$ The idealized understanding of place in the novel is complicated by Cristina's arrival and Javier's return, a reflection of the importance of movement throughout recent Galician history which recalls Stuart Hall's proposal that contrary to essentialist notions of place, identity is dictated more by 'routes', the value of lived experience, than the homophone 'roots' or the pull of origins. ${ }^{42}$ Cristina's identity, as well as her reasons for coming to Ribanova to take her own life, are at first unknown, and she is immediately marked as an outsider, as problematic assumptions about the insularity of the local community are once again reinforced. Javier Aldao confirms that she is in fact a wealthy heiress from the Spanish capital who has no living relatives, a portrayal which challenges the emphasis on roots as a signifier of identity. It is revealed that in her own quest to establish a sense of belonging, Cristina had fantasized about building a relationship with Javier in which the two of them would move to his hometown, as in keeping with centralizing discourse, she harboured a romantic obsession with Ribanova as 'una especie de tierra de promisión, en el lugar idílico donde encontrar la dicha y un espacio propio' (223). The cliché of morriña, the Galician emigrant's nostalgic longing for the homeland, is expressed by Javier and then reappropriated by a character from Madrid who has never even been there. ${ }^{43}$ When Javier spurns Cristina's advances because he is engaged to her best friend, she accuses him of driving her to suicide in the hotel which was once his family's property, attempting to sabotage any chance he might have of reconnecting with his roots and thereby adhering to the patriarchal trope of the hysterical, sentimental woman. Although Cristina's scheme ultimately fails (Javier is absolved and becomes reintegrated into Ribanova), the dogma of state nationalism is reinforced as a character from Madrid mythologizes and attempts to manipulate a Galician community.

The Hotel Almirante itself, the hub of the action which takes place in the novel, represents a broader societal conflict in terms of class, ideology and power, claimed by competing individuals to represent the appropriation of symbolic sites by different groups that 'invest them in meanings which are attuned to their political project or national identity'. ${ }^{44}$ Doreen Massey postulates that spaces are defined by competing social interactions such as those represented by the two rival families, and by default the inherent tensions in Galician identity: 'what is specific about a place, its identity, is always formed by the juxtaposition and co-presence there of particular sets

41 Linda McDowell, Gender, Identity and Place: Understanding Feminist Geographies (Cambridge: Polity Press, 1999), 208.

42 Stuart Hall, 'Introduction: Who Needs "Identity"?' in Questions of Cultural Identity, ed. by Hall and du Gay, pp. 1-17 (p. 4).

43 For further reading on Galician sentimentality as a gendered, colonial stereotype, see Miguélez-Carballeira, Galicia: A Sentimental Nation.

44 Tim Edensor, National Identity, Popular Culture and Everyday Life (London: Bloomsbury Academic, 2016), 46. 
of social interrelations, and by the effects which that juxtaposition and copresence produce'. ${ }^{45}$ Rivera has described hotels as 'no lugares', a fitting location for discussions of identity; her 2016 novel Nosotros, los de entonces, is also set in a hotel. ${ }^{46}$ Static perceptions of belonging are muddied by the comings and goings in this space of transit, as Javier, the outsider estranged from his parents, finds refuge in the former property they refuse to so much as enter, representing the broader context of conflicting ideologies.

The name of the hotel alludes to the importance of seafaring in Galicia, with connotations of mobility, but arguably also recalls the prowess of Francoist naval fleets, many of which were based in the Galician port of Ferrol, the dictator's hometown. Moreover, the hotel is not a neutral space for Javier because of its historical connections to his family, yet he chooses to stay there to spite his father, occupying a liminal position that speaks to Rivera's own ambivalent relationship with Galicia. Upon his arrival, the receptionist notices his neutral accent which does not contain traces of his Galician identity, 'como si no viniese de ningún lugar del mundo' (109), despite having grown up in Ribanova. Javier's Galician identity is questioned in a way which echoes attitudes to Rivera herself, leading to a certain insecurity in his sense of self, for inevitably 'one's identity is the way in which one identifies oneself to others or is identified by them'. ${ }^{47}$ If it rings true that a home, in this case the town of Ribanova, 'may embody the interiority of the self or it may cut across the entire fabric of the nation', ${ }^{48}$ we might extend Alison Blunt and Robyn Dowling's theorization of it as 'multi-scalar', consisting of 'spatialized feelings of belonging and alienation' 49 for the character of Javier, to a broader conception of the inherent tensions in Rivera's 'unhomely' relationship to the Galician nation, whereby she claims sense of estrangement as she is not accepted by certain cultural institutions. The fact that despite being a native of the town, Javier is received by the locals as a well-to-do visitor from Madrid once again suggests that Ribanova tends towards parochialism. Tana is sceptical about the budding romance between Javier and her granddaughter Rosalía, not because of the class difference so much as the clash between rural and urban values, particularly stark in Rivera's depiction of Galicia: 'Mi nieta es una chica de provincias, y Javier Aldao un señorito madrileño' (203). Javier's status as an outsider in Ribanova is reiterated by an image of him reading Camus' L'Étranger (1942),

45 Doreen B. Massey, Space, Place and Gender (Minneapolis: Univ. of Minnesota Press, 1994), 168-69.

46 Marta Rivera de la Cruz, 'Escenarios de leyenda', Mecurio, 172 (June-July 2015), n.p.; available at <http://revistamercurio.es/temas/escenarios-de-leyenda/> (accessed 12 April 2019).

47 Paul Gilbert, Cultural Identity and Political Ethics (Edinburgh: Edinburgh U. P., 2010), 5 .

48 Dwayne Avery, Unhomely Cinema: Home and Place in Global Cinema (London/New York: Anthem Press, 2014), 13.

49 Alison Blunt \& Robyn Dowling, Home (London/New York: Routledge, 2006), 10. 
an example of foreign influence in which, like him (and as claimed by Rivera herself regarding the Galician cultural sphere), the protagonist struggles against the expectations of society (171). In contrast, Ribanova inhabitant Juan Sebastian Arroyo purchases Pabellón de reposo (1943), a novel by Camilo José Cela (1916-2002), a Galician writer who, like Rivera, wrote in Spanish (202). This choice of text for a character who is well-integrated into local society alludes to Rivera's insistence on a Galician identity which is not conditioned by language.

Identities are becoming increasingly fragmented with the influence of globalization and transnational movement, which further complicates the distinction between 'roots' and 'routes', or 'hard' and 'soft'. In Hotel Almirante, Rivera's version of a Galician identity as an amalgamation of both local and global elements influenced by mobility is represented by the stereotypically Galician motif of gastronomy, which also dominates Nosotros, los de entonces. Notably, this theme to an extent complies with the Spanish regionalist discourse which characterised Fraga's Presidency of the Xunta (1990-2005), described by Noa Ríos Bergantinhos as an 'idiosyncratic version of galeguismo [which] placed a series of folkloristic elements of Galizan traditional culture centre stage, giving precedence to the kind of food-related modes of Galizan sociability that have been pithily defined as the 'culture of octopus and bagpipes. ${ }^{50}$ The depiction of Casa Leal, the restaurant set up by Tana in the early 1900 s, solidifies gender and class norms of the time, as it is said to have been frequented by bourgeois men whose wives are not obliged to cook, as well as by working-class housewives seeking to escape the confines of the kitchen. In keeping with almost patronizing cliché, the traditional Galician cuisine appeals to the impoverished locals who know no better:

No es que doña Tana y sus tres hijas no supiesen cocinar más allá de los callos con garbanzos, la carne en salsa o el guiso de calamares, pero el tipo de clientela del mesón no estaba en condiciones de pagar-ni de apreciar tampoco-otras exquisiteces que las Leal eran capaces de preparar. (32)

The extent to which the establishment is renowned for its caldo gallego, the quintessential dish which is said to have changed the course of the Leal family and indeed Ribanova more generally, evokes the enduring importance of archetypal tropes in Rivera's Galicia: 'Muchos dicen que fue el caldo gallego el responsable de todos los acontecimientos que variaron la vida de algunos ribanovenses' (35). Cándido Aldao, who marries Rosa Leal, yearns for caldo gallego when he is working as a food critic abroad, 'más que otra cosa añoraba de su ciudad natal el sabor del caldo' (38), as cuisine is conflated with the classically Galician sentiment of nostalgia. In a Proustian madeleine

50 Noa Ríos Bergantinhos, 'Contemporary Galizan Politics: The End of a Cycle?' in $A$ Companion to Galician Culture, ed. Helena Miguélez-Carballeira, 195-212 (p. 204). 
moment, the authentic flavours trigger childhood memories associated with 'home':

[...] en el momento en que metió en la boca la primera cucharada sintió que volvía al colegio, a sus años infantiles, al regazo materno y a todas las cosas auténticas que creía haber perdido después de tanto tiempo de andar dando tumbos por el mundo. (38)

Rosa demonstrates a certain attachment to local tradition when she discovers upon leaving home that the cuisine of her family restaurant is on a par with the finest establishments in Europe. Yet in a paternalistic manner, exposure to foreign customs prompts her to enhance the restaurant menu, making her critical of her own culinary traditions and evoking the ambivalence in Rivera's relationship with Galicia. Though Tana yearns for the simplicity of the local dishes they cooked before the war; an illustration of the generation gap in the contrast between traditional and new forms of Galician culture, with Rosa's input the Leals begin to experiment with upmarket foreign influences, transforming local cuisine for the benefit of their business, in a reflection of the impact of capitalist globalization on rural communities. This interplay between bounded and malleable notions of the traditionally Galician trope of gastronomy fundamentally recalls the tension inherent in Rivera's Galician identity.

On several occasions, Rivera has been accused of being overtly classist, and although her novel gives an ambivalent portrayal of the Civil War and dictatorship which sanitizes historical memory, it somewhat complicates this perception with a certain emphasis on social mobility, the second theme of note here. ${ }^{51}$ Galician identity has been associated with the rural peasant Volk since Rosalía de Castro vindicated it in her poetry, and the Leal family protagonists are stereotypically working-class Galicians. The traditionally rigid divide in the local feudal system is however subverted through the social mixing of the lower and upper classes, which begins before the social upheaval of the Civil War. Rivera complicates facile assumptions about her own politics by vilifying the Aldaos as Spanish nationalists who adhere to class stereotypes by siding with Franco during the Civil War. In a plausible nod to her in-laws, they are well established as members of the local gentry whose prominence in the town dates back generations, 'su apellido era tan familiar en la ciudad como la muralla milenaria o el salón del Casino' (73). As Spanish-speakers, Rivera's own family comply with linguistic stereotypes of the well-to-do, and it is striking that her novel gives no indication that its lower-class characters speak Galician, as would have been highly likely for individuals from their social background even during the severe linguistic repression under Franco. Of note is the fact that the protagonists of the

51 See Maestre, 'El clasisimo de la candidata de Ciudadanos, Marta Rivera de la Cruz', n.p. 
aristocratic Aldao family are men, whilst the Leals are all working-class women.

When Edmundo Aldao, Javier's great-grandfather, meets his wife Laura in Madrid, accent again becomes a marker of identity as she is attracted to Edmundo's distinct way of speaking and refers to him as 'el guapo de provincias' (35), which suggests that for Rivera, Galician identity defies class boundaries, as even members of the aristocracy are marked out as distinct. Yet Cándido recognizes that vestiges of his upper-class heritage do not hold the same sway beyond Galicia's borders, which alludes to the cultural specificity of the engrained social hierarchy at home, whilst highlighting regional prejudices in central Spain: 'La verdad es que en Ribanova lo de apellidarse Aldao tiene sus ventajas. En Madrid, sin embargo, no me vale para nada' (41). Despite being a nobleman, Edmundo befriends Tana Leal when frequenting her restaurant, thereby to some degree subverting established narratives of class identity, though she is still in a role of servitude and the friendship is somewhat hidden from society. When his nephew Cándido proposes to Rosa Leal, the family disapproves of the match, as their inherited privilege is directly threatened by her lowly social status, yet the couple defy convention by getting married. The text again plays with social strata through Rosa's shock at Cándido's premature death from gluttony rather than destitution, a palpable risk for lower socio-economic sectors of society during the dictatorship. Contrary to societal assumptions, he in fact dies penniless, leaving only the ancestral home to Rosa in his will. When the Aldaos try to use the weight of their status and wealth to put pressure on the Leals to sell their former property back to them, fixed notions of identity are once again challenged as their behaviour does not conform to class stereotypes: 'Pensaba yo que la gente fina hablaba más bajo' (54). Tana succeeds in standing her ground despite her subjugated position due to both her gender and her class, so that she defies the traditionally rural, patriarchal class system to assert a lower-class, female-oriented and indeed urban Galician identity: 'A nadie pasó inadvertido el hecho de que cuatro mujeres desconocidas para la buena sociedad ribanovense abriesen con su propia llave la puerta de la casona Aldao' (55). As a symbol of modernity, the hotel and its fusion cuisine might also point to the tensions inherent in a 'rurban' (neither rural nor urban) or 'post-rural' Galicia, the amalgamation of influences characterized by Neil Anderson, drawing on José Colmeiro, as 'a collective feeling of relation to rural spaces that is coloured by a rapid process of modernization and deruralization that disarticulates that culture'.52 The hotel implements a new social order in the town to symbolically consolidate the links between identity, power and monument, as the dying feudal system is replaced by a modern, classless one that

52 Neil Anderson, 'To Be or Not: The Rural Village in Post-Rural Times', Galicia 21, F (2014-2015), 61. 
strikingly, given the Francoist setting, is based on female entrepreneurship. Although the Aldaos refuse to so much as enter the building, their prodigal son Javier makes the hotel his place of refuge, muddying the class divide like Cándido before him and claiming a sense of belonging that challenges the stereotypical image of the Galician as peasant. The sense of Galician identity put forward here is progressive in that it does encompass aspects of class mobility and societal change.

The depictions of the impact of the Civil War in Galicia, and specifically Javier's exile, however, are starkly apoliticized in a way which complies with the writer's conservative stance. The suicide of an outsider provokes a flurry of town gossip, as it is claimed to be 'el único suceso extraordinario ocurrido en la ciudad desde el fin de la guerra' (91), showing a blatant disregard for the harsh reality of life under Franco's dictatorship. Owing to Ribanova's remote location, most of its citizens are said to be living in denial about the war and its aftermath, which is mentioned only as a back-drop:

Ribanova era un lugar suspendido en el tiempo, y había quien pensaba también en el espacio, como si la muralla estuviese empeñada en aislar a la villa del resto del planeta. Ni siquiera la Guerra Civil había sido capaz de cambiar el orden natural de las cosas cotidianas en aquella ciudad de lluvias eternas. (91-92)

This dilution of the severity of the bloodshed, repression and collective trauma caused by the conflict in Galicia serves as a romanticized, one-sided and problematic version of history, even for a fictional work: 'había veces que olvidaban incluso que el país estaba en guerra, como si todo el mundo se hubiese puesto de acuerdo para, en la medida de lo posible, impedir que el desastre fratricida entrase en sus vidas' (92). The emphasis here on 'forgetting' complies with the right-wing avoidance of truth and reconciliation regarding the dictatorship that was counteracted by the socialist government's introduction of the Ley de la Memoria Histórica in 2007, but which continues to have a considerable bearing on contemporary Spanish politics. Javier is hailed as a hero because he rebels against his conservative upbringing by fighting for the Republican army: 'Para una rancia familia de provincias, la presencia activa de un hijo en el frente republicano constituía un auténtico baldón, una lacra sobre la que era preciso echar tierra cuanto antes' (218), though the sympathetic representation of a protagonist who fights for the Republican army does not evade Taibo's assertion regarding discourses of contemporary Spanish nationalism which sanitize the past and 'gustan de alardear de su antifascismo de siempre como carta de presentación de sus querencias contemporáneas'. ${ }^{53}$ Echoing the fate of many Galicians during Francoism, Javier was sent into exile because of his left-wing politics, yet in his case, this is merely due to his father's

53 Taibo, Sobre el nacionalismo español, 33. 
disapproval, rather than persecution by the authorities. The harrowing consequences of the regime for Republicans are brushed over in the novel, as Javier only goes as far as Madrid, rather than having to flee further afield. He admits that his decision to fight for the Republicans consisted more of a childish rebellion than an ideological stand, which complies with Rivera's conservatism. Javier's non-committal attitude only serves to perpetuate the classism that his actions had originally challenged and somewhat undermines the promotion of social mobility:

No soy una persona de convicciones firmes. Simplemente encontré muy atractiva la idea de enfrentarme a mi mundo. Luchar con la República fue una forma de rebeldía casi infantil y bastante absurda. A mi lado murió gente que peleaba por unos ideales mientras yo pegaba tiros sólo para llevar la contraria. (189)

His insurgency and exile are further undermined by his estranged father using Falangist connections to secure his release from prison. Though Javier is shown to be more tolerant and forward-thinking than his parents, the novel conspicuously evades placing blame in relation to the Civil-War conflict, in accordance with Rivera's right-wing leanings, thereby misrepresenting the reality of exile and persecution during the dictatorship.

Whilst Javier is sent away by his conservative, upper-class family for his Republican views, Rivera too claims she is shunned in Galicia for her politics, conversely reporting that she has been marginalized by Galician nationalism for what can be deemed her Spanish nationalist tendencies. Unlike Javier, however, she lives in Madrid out of choice and stands by her views, whilst Javier in the end takes a non-partisan stance and tries to make peace with his family. The challenges Javier faces in adapting to life in his hometown after a period of forced detachment from an integral part of his identity allude to Rivera's own complicated relationship with Galicia, whilst highlighting the impact of emigration, and by extension exile, on the Galician psyche: 'ése era el precio que tenía que pagar él: la renuncia a todo aquello que consideraba parte de su historia' (108). Paul Tabori affirms the exile's painful longing to return, 'hoping to return to his fatherland when circumstances permit-but unable or unwilling to do so as long as the factors that made him an exile exist', and though Javier never manages to reconcile with his family or their bourgeois values, he manages to reassert a new sense of belonging that takes into account his emigrant experience. ${ }^{54}$ Visiting his old haunts as he attempts to work through the ordeal of being disowned by his family (a plot device which conspicuously erases the real trauma faced by exiles of Francoism) and 'la melancolía para avivar el alma dormida' (194), he reaffirms his roots in Ribanova independently from family ties, assuming a new, created sense of self which dismantles the notion of identity as a fixed

54 Paul Tabori, The Anatomy of Exile: A Semantic and Historical Study (London: Harrap, 1972), 27. 
entity and speaks for Rivera's claim to an alternative 'Galicianness' that accounts for her self-proclaimed metaphorical 'estrangement' from the Galician cultural system, but also highlights her fundamentally Spanish regionalist agenda.

A final point for consideration in relation to Rivera's assertion of Galician identity is the fact that Hotel Almirante is dominated by emancipated female characters, bearing some parallel to the intersections of progressive Spanish feminism and Galician feminist nationalism. However, Spanish conservatism is apparent in how the novel overlooks, or at the very least romanticizes, the historical reality of the oppression of women under Franco. Rivera's party has distanced itself somewhat from mainstream feminism and put forward a rather ambiguous interpretation of 'feminismo liberal' on International Women's Day, 8 March 2019. ${ }^{55}$ The writer herself has spoken out in favour of gender equality, commenting that 'el camino a la igualdad es muy largo y queda, tristemente, mucho terreno por recorrer', though she has been heavily criticized for her denial of the role of gender in domestic violence. ${ }^{56}$ This apparent contradiction in Rivera's feminism is paralleled in her fiction, as women's experiences and indeed their contributions to society, though almost entirely absent from Linus Daff, inventor de historias, for example, are at times a core concern; two of her children's books, Mi primer libro sobre ellas and Ellas hicieron historia, were written to mark the centenary of International Women's Day in 2011 and centre on historical women who fought for their rights. Toril Moi asserts that 'to turn women into second-rate citizens in the realm of literature is to say that women's experiences of existence and of the world are less important than men's', and as we have seen, the Galician society depicted in Hotel Almirante combats

55 On the 'feminismo liberal' of Ciudadanos, see 'Ciudadanos: Manifiesto Feminismo Liberal' <https://www.ciudadanos-cs.org/manifiesto-feminismo-liberal>; J.C., 'Ciudadanos presenta su "feminismo liberal": a favor de la gestación subrogada y contra el lenguaje inclusivo', Público, 3 March 2019, n.p.; available at $<$ https://www.publico.es/politica/feminismo-ciudadanos-ciudadanos-presenta-feminismoliberal-favor-gestacion-subrogada-lenguaje-inclusivo.html> and E.O., 'Rivera defiende el feminismo liberal por el 8 de marzo: "En materia de igualdad no hay que dar pasos a izquierda o derecha", 20 minutos, 8 March 2019, n.p.; available at $<$ https://www.publico.es/politica/feminismo-ciudadanos-ciudadanos-presenta-feminismoliberal-favor-gestacion-subrogada-lenguaje-inclusivo.html> (all accessed 12 April 2019).

56 On Rivera's feminism, see Marta Rivera de la Cruz, 'Feminismo como argumento político, ¿pose o herramienta electoral?', Glamour, 26 May 2014, n.p.; available at $<$ https://www.glamour.es/placeres/cultura/articulos/feminismo-como-argumento-politicopose-o-herramienta-electoral/19916>. On her comments on domestic violence, see Angélica Rubio, 'Quitar el agravante machista es negar la violencia de género', El Plural, 11 December 2015, n.p.; available at <https://www.elplural.com/20d-candidaturas/quitar-el-agravantemachista-es-negar-la-violencia-de-genero_82539102>; and Anon., 'La representante de Ciudadanos, cuestionada por su actuación en el debate', Huffington Post, 10 December 2015, n.p.; available at <https://www.huffingtonpost.es/2015/12/10/marta-rivera-de-lacruz_n_8766870.html> (all accessed 12 April 2019). 
this issue through its focus on a female business venture. ${ }^{57}$ Tana conforms to the stereotype of the Galician working woman, taking on the stereotypically masculine role of bread-winner as well as the more quintessentially feminine attributes of caregiver. After being widowed at a young age, she supports her three daughters with her thriving restaurant business, combining the supposedly feminine propensity for cooking with entrepreneurial skills. Her good business sense subverts stereotypes about her gender as well as her class, for she is said to have received very little formal education, as was the case for so many in her position at the turn of the century. She even manages to keep the business afloat during the war, which downplays the reality of hardship and chaos, complying with the text's evasion of memory politics.

In a more two-dimensional representation that reinforces the essentialist association of women with the domestic sphere, the characterization of Tana's three daughters is relatively underdeveloped, yet they are said to have inherited their mother's flair for cooking with which they reclaim the kitchen as their 'ámbito de poder' (174) in a male-dominated society. In fact, it is in the domestic, 'feminine' sphere where the effects of the Civil War are most apparent, as unlike many Galicians, the Leals have the means to obtain goods from the black market both during and after the war. Tana reinforces patriarchal discourse of the time with her belief that her daughters' 'pasion por el arte de la cocina podía ser una forma cualquiera de dar sentido a sus vidas' (49); a primary concern due to their lack of conformity in terms of marriage and motherhood. Yet Candela challenges societal norms when she gives birth to Rosalía out of wedlock, and it is important to note that despite the pressures of society, an illegitimate baby girl is considered a blessing, 'Es una chica. Mucho mejor-dijo en cuanto la vio-. Dan menos problemas que los muchachos' (32), consolidating the strong female bond which binds their family. The child is named Rosalía (shortened to Lía) after Rosalía de Castro, because in a reinforcement of stereotypical perceptions of Galicians, she is said to have a melancholic personality like the great Galician writer, but most significantly grows up to be an example of female strength and societal change. ${ }^{58}$ Rosalía's indifference to Javier's stereotypically feminine gift of flowers, 'y después de poner las flores en un jarrón de agua, volvió a sus papeles' (191), asserts her traditionally 'masculine' ambition and suggests the importance of female contributions to Rivera's vision of Galicia.

As a contrast to this foregrounding of domestic 'power' and femalecentred business, the characters of Cristina and Javier's fiancé Andrea, nonGalicians who belong to Madrid high society, are shown to signify contrasting and problematic stereotypes of femininity. Andrea is described as the epitome of the bourgeois and indeed Francoist ideal of feminine fragility and

57 Toril Moi, “"I Am Not a Woman Writer”: About Women, Literature and Feminist Theory Today', Feminist Theory, 9:3 (2008), 259-71 (p. 268).

58 María Candel, 'Escribir desde la melancolía: una aproximación a la figura de Rosalía de Castro', Revista de Cultura Almiar, 47 (2009), 1-13. 
innocence, whilst Javier relishes his patriarchal, dominant role in their relationship: "le producía una palmaria satisfacción la certeza de que su novia sólo viera por los ojos de él, y que le consultara todas y cada una de sus decisiones' (219). Cristina, on the other hand, subscribes to the women-aswitch stereotype - a hysterical, manipulative woman who stalks Javier and spreads the rumour that they are having an affair, with her evident mental illness barely dealt with in the text. ${ }^{59}$ Cristina's attempts to destroy Javier's relationship with Andrea assert patriarchal female competitiveness over men. For Andrea, this betrayal of female solidarity is more damaging than the prospect of Javier's infidelity-'Andrea había podido superar una traición de su novio, pero no de la que consideraba su mejor amiga' (226)—which leads to her early demise. The two-dimensional Madrid women stand in contrast to the Galician women, whose more overtly feminist characterization evokes a progressive Galician identity that is conscious of female voices and experiences.

When Cristina's body is discovered in Ribanova, we bear witness to the patriarchal fixation of representatives of masculine authority, namely police officer, judge, mayor and doctor, on the exotic 'belleza sobrehumana' (93) of an unknown woman. Rosalía challenges the doctor's sexism when he suggests Cristina took her own life due to unrequited love, though the plot in fact confirms this assumption:

-A sus años, y siendo tan guapa, una mujer sólo puede querer morirse por culpa de un amor contrariado.

-Ustedes, los hombres, lo reducen todo a una cosa.

-No, señorita. Son las mujeres quienes lo hacen. (15)

Yet the text does play with this patriarchal attitude, as the doctor is repulsed when his evidence is used to prove that Cristina did not have sexual relations with Javier. Overall, and in spite of some essentialist portrayals of the female characters, it can be inferred that Rivera's Galician identity is informed to a degree by a concern for gender-inclusivity, with contradictions that could be said to correspond to her politics. Traditional notions of territory, class and gender are superseded by a new social order that sits uneasily with traditional stereotypes of the downtrodden Galician peasant, though certain underlying discourses of patriarchal Spanish regional identity remain.

Perhaps Rivera reinforces the very conflation of language and identity that she seeks to challenge, for even as her Spanish-language fiction does assert her take on Galician culture, it remains somewhat shackled by the influence of state centralism. Whilst on the surface it appears to be an apolitical detective story, Hotel Almirante in fact packages an interpretation

59 See Susan Brownmiller's seminal study Femininity (New York: Linden Press/Simon \& Schuster, 1984), and Marianne Hester, Lewd Women and Wicked Witches: A Study of the Dynamics of Male Domination (London: Routledge, 1992). 
of Galicia for a Spanish-language readership that simultaneously reinforces and subverts the author's conservative ideological stance regarding gender and class, and to some extent, national identity. Aside from a paternalistic focus on the benefits for Galicia of global influence and the especially problematic romanticization of the Civil War and dictatorship, Hotel Almirante reconfigures certain rigid notions of reflective identity that can be attributed to more conservative Spanish regionalist writing. Though Rivera might be dismissed as a cultural sell-out, her continued presence on the Galician stage, as both a writer of contention and a vocal member of the Spanish Parliament, implicates readers, citizens and cultural bodies alike in her conflictive views. The writer stakes her claim as a contributor to Galician culture who cannot, and should not, be overlooked. For if her work demands reappraisal of Galician identity, it also at times unsettles what it means to be Spanish.*

* Disclosure Statement: No potential conflict of interest was reported by the author. 